\title{
Factors associated with presenteeism in nursing workers
}

\author{
Fatores associados ao presenteísmo em trabalhadores de enfermagem \\ Factores asociados al presentismo en trabajadores de enfermería
}

\author{
Bruno da Silva Santos' \\ ORCID: 0000-0002-3677-6287 \\ Fernanda Ludmilla Rossi Rocha" \\ ORCID: 0000-0002-0911-3728 \\ Juliano Bortolini' \\ ORCID: 0000-0003-0126-3040 \\ Fábio de Souza Terra"' \\ ORCID: 0000-0001-8322-3039 \\ Marília Duarte Valim' \\ ORCID: 0000-0002-2746-1865
}

'Universidade Federal de Mato Grosso. Cuiabá, Mato Grosso, Brazil.

"Universidade de São Paulo. Ribeirão Preto, São Paulo, Brazil. "' Universidade Federal de Alfenas. Alfenas, Minas Gerais, Brazil.

How to cite this article:

Santos BS, Rocha FLR, Bortolini J, Terra FS, Valim MD. Factors associated with presenteeism in nursing workers. Rev Bras Enferm. 2022;75(1):e20201290. https://doi.org/10.1590/0034-7167-2020-1290

\section{Corresponding author:}

Bruno da Silva Santos

E-mail: bruno.ufmt@hotmail.com

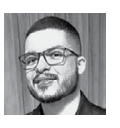

EDITOR IN CHIEF: Antonio José de Almeida Filho ASSOCIATE EDITOR: Ana Fátima Fernandes

Submission: 11-28-2020

Approval: 03-20-2021

\begin{abstract}
Objective: to analyze factors associated with presenteeism in nursing workers with sociodemographic variables, health and work conditions, productivity and musculoskeletal symptoms. Methods: this is a cross-sectional, descriptive and analytical study, with 306 nursing workers from a hospital and municipal emergency room in a Brazilian capital. The Stanford Presenteeism Scale, the Work Limitations Questionnaire, the Nordic Musculoskeletal Questionnaire and a demographic questionnaire on nursing professionals' working conditions and health were used. Bivariate and multivariate analyzes were performed, respecting a significance level of $5 \%$. Results: presenteeism was found in $43.8 \%$ of professionals and significant associations with CLT work ( $p=0.002)$, workplace - Intensive Care Units $(p=0.008)$, physical exercise twice a week $(p=0.008)$, presence of musculoskeletal symptoms, with low back pain being representative $(p=0.001)$. The productivity loss was 8.8 . Conclusions: the study confirms a high rate of presenteeism among nursing workers.

Descriptors: Presenteeism; Nursing; Worker's Health; Efficiency; Cumulative Trauma Disorders.
\end{abstract}

\section{RESUMO}

Objetivo: analisar fatores associados ao presenteísmo em trabalhadores de enfermagem com variáveis sociodemográficas, condições de saúde e trabalho, produtividade e sintomas osteomusculares. Métodos: estudo transversal, descritivo e analítico, com 306 trabalhadores de enfermagem de um hospital e pronto-socorro municipal de uma capital brasileira. Utilizaramse o Stanford Presenteeism Scale, o Work Limitations Questionnaire, o Questionário Nórdico de Sintomas Osteomusculares e um questionário demográfico de condições de trabalho e saúde dos profissionais de enfermagem. Realizaram análises bivariadas e multivariadas, respeitando um nível de significância de 5\%. Resultados: o presenteísmo foi constatado em $43,8 \%$ dos profissionais e associações significativas com o regime de trabalho celetista $(p=0,002)$, local de trabalho - Unidades de Terapia Intensiva $(p=0,008)$, prática de exercícios físicos 2 vezes por semana $(p=0,008)$, presença de sintomas osteomusculares, sendo a dor lombar representativa $(p=0,001)$. A perda de produtividade foi de 8,8 . Conclusões: o estudo confirma alto índice de presenteísmo entre trabalhadores de enfermagem.

Descritores: Presenteísmo; Enfermagem; Saúde do Trabalhador; Eficiência; Transtornos Traumáticos Cumulativos.

\section{RESUMEN}

Objetivo: analizar factores asociados al presentismo en trabajadores de enfermería con variables sociodemográficas, condiciones de salud y trabajo, productividad y síntomas musculoesqueléticos. Métodos: estudio transversal, descriptivo y analítico, con 306 trabajadores de enfermería de un hospital y urgencias municipales de una capital brasileña. Se utilizo el Stanford Presenteeism Scale, el Work Limitations Questionnaire, el Cuestionario Nórdico Musculoesquelético y un cuestionario demográfico sobre las condiciones laborales y de salud de los profesionales de enfermería. Realizaron análisis bivariados y multivariados, respetando un nivel de significancia del $5 \%$. Resultados: se encontró presentismo en el $43,8 \%$ de los profesionales y asociaciones significativas con el régimen de trabajo celetista $(p=0,002)$, lugar de trabajo - Unidades de Cuidados Intensivos $(p=0,008)$, ejercicio físico dos veces por semana $(p=0,008)$, presencia de musculoesquelético síntomas, siendo la lumbalgia representativa ( $p=0,001)$. La pérdida de productividad fue de 8.8. Conclusiones: el estudio confirma una alta tasa de presentismo entre los trabajadores de enfermería.

Descriptores: Presentismo; Enfermería; Salud del Trabajador; Eficiencia; Trastornos Traumáticos Acumulativos. 


\section{INTRODUCTION}

Presenteeism is seen in literature in a conceptual, recent and heterogeneous way and concerns the attendance of professionals at their workplace, even if they feel sick, whether physically or psychologically ${ }^{(1-3)}$.

The definitions of this phenomenon have reference to the physical presence in the workplace, but they may present differences in its content ${ }^{(3)}$. These definitions are directly related to the decrease in productivity as a result of some health problem. In this condition, individuals present themselves to work below their capacity to perform well, which legitimizes them as sick ${ }^{(3-4)}$.

Presenteeism has been cited in literature as a problem nowadays, and recent studies have demonstrated its impact on the finished work, causing a decrease in the productivity of this worker, with consequent losses for organizations, as well as negative repercussions on quality of care that will reflect no patients ${ }^{(3,5-7)}$.

Literature points to some factors that can be considered as research criteria to explain the phenomenon of presenteeism. Some of these factors are related, for example, to the possible consequences of overwork and feeling of insecurity that workers are experiencing in the contemporary world ${ }^{(8)}$.

The new labor relations that are being established, the high unemployment rates, the constant restructuring of the public and private sectors, the decrease in the size of organizations, with the reduction in the number of workers, the increase in temporary hires and the reduction of labor benefits they must also be considered as criteria to be observed in the search for explanations about presenteeism ${ }^{(8)}$.

One of the major repercussions of the presenteeism phenomenon for institutions is related to the loss of productivity, which can be justified by the low performance of these workers, due to their eventual physical and/or emotional problems. Several situations can put a worker in present conditions. Among them, the dedication to work, the fear of overloading teammates and the loss of labor benefits due to leave or absences stand out ${ }^{(9-10)}$.

With regard to nursing work, it is observed that presenteeism has as its main outcome the loss of productivity, both in quantity related to physical and mental performance and in quality, when it comes to increasing the possibilities of errors ${ }^{(6)}$. This decreased productivity can be explained by workers who are limited both physically and mentally, since excessive demands affect the body, due to physical efforts, during their care actions, hindering the cognitive performance of professionals, in addition to generating impaired interpersonal interaction ${ }^{(3)}$.

Another relevant aspect that deserves to be highlighted is that Work-related Musculoskeletal Disorders (RSI/WMSD) are frequent among nursing workers and result in reduced physical performance, increasing labor costs and organizational costs, causing psychological distress and dissatisfaction with work. Such consequences have a close connection with the loss of productivity related to health conditions, which can also result in presenteeist situations ${ }^{(11)}$.

However, for the nursing team, presenteeism is still considered a poorly diagnosed problem ${ }^{(12)}$ that can be related to several factors. Considering the aforementioned information, the National Agenda for Health Research Priorities ${ }^{(13-14)}$ guides the carrying out of investigations related to working conditions for health professionals, work risks to workers' health (chemical, physical, biological, psychosocial ergonomic), work-related illnesses, the effects of precarious work on workers' health, the economic impact for the Brazilian Unified Health System (SUS - Sistema Único de Saúde) and, finally, data that confirm the relationship between productivity and bonds health professionals in SUS.

With this, it is justified to carry out this study in order to fill gaps that still exist in science in relation to this theme, mainly at national level, in center-western Brazil and with the results found, favor the creation of public policies and actions aimed at these professionals aiming at a better adjustment of their working conditions.

Thus, the present study sought to answer the following questions: what is the frequency of presenteeism in nursing workers in a hospital and municipal emergency room in a capital city in center-western Brazil? What is the frequency of musculoskeletal symptoms in these workers? What sociodemographic, working conditions and health factors are associated with presenteeism in these nursing workers?

\section{OBJECTIVE}

To analyze factors associated with presenteeism in nursing workers with sociodemographic variables, health and work conditions, productivity and musculoskeletal symptoms.

\section{METHODS}

\section{Ethical aspects}

This study was sent to an Institutional Review Board, and all of its development complied with the ethical and legal precepts of Resolution 466/2012 of the Brazilian National Health Council (Conselho Nacional de Saúde). Data collection started after all participants' doubts had been clarified and after the Informed Consent Form was signed.

\section{Study design, period and place}

This is a cross-sectional, descriptive and analytical study, carried out from October 2019 to January 2020 in a hospital and municipal emergency room in a capital city in the Center-West of Brazil. Said hospital is a health institution of a legal nature, of public administration and municipal management, the main maintainer of which is the Municipal Health Department (MHD). Characterized as a general hospital, open 24 hours a day, including Saturdays, Sundays and holidays, it has 371 hospital beds, divided into several medical specialties of medium and high complexity.

\section{Population/sample: inclusion and exclusion criteria}

In 2019, the institution had 458 nursing professionals. To define the population, all professionals were selected using the inclusion criteria. Thus, the study included workers with at least 6 months of work at the institution, excluding those who were away from work due to sick leave or maternity leave or when they were leaving the hospital. 
After the referred stage, all nursing workers at the institution were invited to participate in the study after previous individual contact made by the researchers. Upon signing the Informed Consent Term (ICF), professionals received the research collection materials in hand, as they are self-administered instruments. Then, these materials were returned by 306 nursing professionals who made up the final study population.

\section{Study protocol}

Each participant received a sealed envelope containing the study instruments that would be answered and delivered until the next shift that the respective professional was scheduled. Then, the material was collected by the researchers, who had the control of participants through the institution's nursing shift scale. In order to facilitate the process and not damage the service's work routines, the hospital's permanent education sector provided a room for the institution's educational activities if participants wished to use it to fill it out. It is important to point out that there was no involvement with hospital management at the time of data collection, with only the researcher and participants gathered, in order not to interfere in their work routine and not to exert influences that might not correspond with the objectives of the study.

Four instruments were used: the Sociodemographic Questionnaire of Work Conditions and Health of Nursing Professionals (QSCTS), the Stanford Presenteeism Scale (SPS6), the Work Limitations Questionnaire (WLQ) and the Nordic Musculoskeletal Questionnaire (QNSO).

QSCTS was developed by the researchers and aimed to outline participants' sociodemographic profile with information relevant to social, economic, professional training, work and health conditions. It is a semi-structured questionnaire, containing 64 nominal and 8 numeric variables. The questionnaire was based on studies that investigated factors that may be related to the phenomenon of presenteeism, being validated in terms of face and content by a panel of six judges who are experts in the theme of occupational health, mental health, nursing administration and two professionals who worked for at least two years in nursing care, represented by a nurse and a nursing technician. Each question was analyzed and discussed regarding its clarity and the need to adapt to the research theme. The agreement index reached was 0.90. In its initial version, the questionnaire had 43 items, divided into 4 categories. During its validation process, there were a total of 9 items excluded and an increase of 4 new items, ending the process with 38 items divided into 5 categories, establishing face and content adequacy according to statements' pertinence.

SPS6, developed by researchers at Stanford School of Medicine and the American Health Association, is indicated for studies that assess health and productivity conditions. It is a Likert-type ordinal scale (1-5), with 5 response modalities ranging from: 1 totally disagree to 5 totally agree, consisting of 2 dimensions of 3 items each, the first being associated with the "finished work" construct, and the second, "maintained concentration", totaling 6 questions ${ }^{(15)}$. To answer the questionnaire, firstly, participants need to say if they have been working in the past 30 days with any health problem and, if the answer is affirmative, they must proceed with filling out the instrument.
To obtain the total score of SPS6, add the points answered, which can vary from 6 to 30 points. The authors of the original version determined that the score classified as low (from 6 to 18 ) indicates a reduction in performance and high scores (from 19 to 30 points) correspond to a greater ability of workers to concentrate and perform all the work, despite presenting some health problem ${ }^{(15)}$. The scale was adapted to Brazilian Portuguese in 2012 , showing good psychometric properties ${ }^{(12)}$. Its use in the present study was authorized by the authors.

WLQ represents a self-administered questionnaire consisting of 25 items, the purpose of which is to measure the degree of interference that health problems bring to individuals' ability to perform their tasks at work, as well as the impact they have on worker productivity. The instrument is composed of 25 items, distributed in 4 domains, being: time management corresponding to question 1 (5 items) that verifies difficulties in fulfilling schedules and tasks in the expected time; physical demand that corresponds to question 2 ( 6 items) and that assesses the ability to perform tasks that require body strength, endurance, movement, coordination and flexibility; interpersonal mental demand, represented by questions 3 and 4 ( 9 items, of which 6 measure the difficulty of performing cognitive tasks at work and 3 items address the difficulty of interacting with people at work); finally, the demand for production domain represented by question 5 ( 5 items), which verifies decreases in the person's ability to complete the necessary quantity and quality of work in a timely manner ${ }^{(16)}$.

WLQ is considered a simple and easy to apply instrument, with a mean filling time of between five and ten minutes. Its version translated and adapted to Brazilian Portuguese was considered satisfactory, easy to apply, with good reliability and validity and with the recommendation of its use in the Brazilian population ${ }^{(16)}$. Copyrights are under the responsibility of the Mapi Research Trust, Lyon, France, at the following virtual address: https://eprovide.mapi-trust.org. To use the instrument, the authorization of the aforementioned company is required, which was promptly granted to carry out this study.

Each of the domains has a scale ranging from 0 to 100 (without limitation - limitation at all times), whose score indicates the percentage in time, indicating that workers have been limited to carry out their work tasks in the last two weeks. For example, an individual who has a score of 20 on any of the scales had $20 \%$ of the limited time to perform the respective activity. After calculating the scores for each domain, the global WLQ score is defined, which is calculated using a specific formula developed by the authors of the original version of the instrument ${ }^{(17)}$.

Thus, to calculate the score for each domain of WLQ, arithmetic means were calculated, and, subsequently, the formula [WLQ Scale Score $=25^{*}$ (mean item score- 1$]$. After this calculation, the WLQ Index was estimated using the formula [WLQ Index $=(\beta 1$ $X$ WLQ Time management $+\beta 2 X$ WLQ Physical demand $+\beta 3$ $X$ WLQ Mental-interpersonal demand $+\beta 4 X$ WLQ Production demand), in which $\beta 1=0.00048, \beta 2=0.00036, \beta 3=0.00096$ and $\beta 4=0.00106$. With the WLQ Index value, the Global Workplace Productivity Loss was calculated using the formula [WLQ At-Work Productivity Loss Index=(1-exp (-WLQ Index)].

As for QNSO, it had its first version published in 1987 under the original title Nordic Musculoskeletal Questionnaire (NMQ), 
whose proposal was to standardize the measurement of reports of musculoskeletal symptoms, in order to facilitate the comparison of results between studies that seek to measure such construct ${ }^{(18)}$. Translation into Brazilian Portuguese was carried out in 2002, showing satisfactory concurrent validity and reliability indexes ${ }^{(19)}$.

QNSO is basically constituted in an anatomical map, presenting, in topographic form, several regions of the human body, having multiple or binary choices regarding the occurrence of musculoskeletal symptoms in the different regions. Participants must report the occurrence of possible symptoms referring to two different moments, considering the last 12 months and the last 7 days, respectively, both preceding the data collection date. Moreover, they must also report the occurrence of absence from work activities in the last year ${ }^{(18-19)}$. This instrument is available in the public domain and does not require authorization for use.

\section{Analysis of results, and statistics}

The data were organized in spreadsheets and later exported to the $\mathrm{R}^{\circ}$ statistical program, version 3.6 .3 (2020). The numerical variables were presented by descriptive statistics and the mean, median and standard deviation were calculated; categorical variables are presented in tables with relative and absolute frequency distribution. To verify the possible associations between the instruments and the numerical variables, the Mann-Whitney test was applied, since the normality in the data evidenced by the Shapiro Wilk test was not verified. For dichotomous and categorical variables, Pearson's chi-square test was used to compare whether there was a significant association between the variables studied. For all analyzes performed, the level of significance adopted was $5 \%$.

\section{RESULTS}

The response rate obtained by participants was $66.8 \%$, since 306 professionals adequately returned to data collection, which were represented by 86 nurses (28.1\%) and 220 nursing technicians (71.9\%). Regarding sociodemographic characteristics, women were predominantly represented by 260 (85.0\%) of the sample's professionals. Of the total number of workers, 182 (59.5\%) were younger than 40 years old, 119 (39.0\%), aged between 41 and 60 years and 5 workers (1.6\%) were older than 60 years, with a mean age of 39.3 years (median 38; standard deviation 9.3). Finally, 138 professionals ( $45.0 \%$ ) declared themselves single, $123(40.1 \%)$ were married and a total of $215(70.3 \%)$ said they had one or more children.

Regarding the type of bond maintained by these professionals, 184 (62.3\%) had a contract governed by the Consolidation of Labor Laws (CLT - Consolidação das Leis do Trabalho), 111 (37.6\%) were permanent (statutory) and 4 (0.1\%) had a commissioned/outsourced link.

As for the sectors in which these workers work, 177 (58.0\%) worked in inpatient units/clinics (medical/surgical), 93 (30.3\%), in Intensive Care Units (ICU) and 36 (11.7\%) worked in the emergency sector. In relation to work shift, 106 (34.6\%) worked during the day in shifts of $12 / 36$ hours, 87 (33.0\%), full-time with 6 to 8 hours in the day,
70 (23.0\%), at night shifts of 12/36 hours and 41 (13.3\%), at night, on a $12 / 60$ hour basis. Regarding the number of work contracts, 81 (26.5\%) professionals said they had a second job, with greater representation in the night shift in a 12/36 hour regime with 33 workers (41.2\%), followed by a $12 / 36$ hour day shift, represented by 18 professionals ( $22.5 \%)$.

In an analysis of participants' health conditions, 35 (11.4\%) reported using cigarettes, on average, 4 units per day, 89 (29.1\%) said they drink alcohol at least twice a week and 64 (21.0\%) said they used regular/continuous medication. Regarding the practice of physical activity, 76 (24.8\%) claimed to perform some activity, and the frequency reported by 17 professionals (21.0\%) was at least once a week, 32 (42.1\%) Twice a week and 27 (35.5\%) 3 times a week or more.

When asked about having suffered an occupational accident (OA) in the last year, 27 (8.8\%) answered affirmatively; of these, 17 (63\%) were caused by sharps with or without potentially contaminated biological waste. The other OA were related to situations of falls, torsions, burns and other.

Presenteeism was identified in 134 workers (43.8\%). Thus, the study outcome variable, obtained from participants' responses through SPS6, is shown in Table 1.
Table 1 - Distribution of frequencies of the general score and dimensions of Stanford room, Center-West, Brazil, 2019-2020 $(n=306)$ *

\begin{tabular}{|c|c|c|c|c|c|c|}
\hline Variables & $\mathrm{n}^{*}$ & $f(\%)$ & Interval & Mean & Median & $S D^{\ddagger}$ \\
\hline \multicolumn{7}{|c|}{ Worked in the last 30 days with any health problem } \\
\hline Yes & 134 & 43.8 & & & & \\
\hline No & 172 & 56.2 & & & & \\
\hline Total & 306 & 100 & & & & \\
\hline \multicolumn{7}{|l|}{ SPS6 } \\
\hline 6-18 points & 51 & 42.5 & & & & \\
\hline 19-30 points & 69 & 57.5 & & & & \\
\hline Total $^{+}$ & 120 & 100 & $10-30$ & 19.6 & 19.0 & 3.6 \\
\hline Dimension 1 - Finished work & $120^{+}$ & 100 & 3-15 & 8.5 & 8.0 & 3.3 \\
\hline Dimension 2-Maintained concentration & $120^{+}$ & 100 & 3-15 & 11.1 & 12.0 & 3.2 \\
\hline
\end{tabular}

As for the productivity loss of workers related to presenteeism, according to the WLQ At-Work Productivity Loss Index, a drop of $8.8 \%$ was identified, with the global score WLQ Index $=0.08$, as shown in Table 2.

Table 2 - Scores of domains and global score of the Work Limitations Questionnaire for nursing professionals in a hospital and municipal emergency room, Center-West, Brazil, 2019-2020 ( $n=306)$

\begin{tabular}{cccc}
$\begin{array}{c}\text { WLQ } \\
\text { dimensions }\end{array}$ & $\begin{array}{c}\text { WLQ Domain } \\
\mathbf{X}\end{array}$ & $\begin{array}{c}\text { WLQ } \\
\text { Index }\end{array}$ & $\begin{array}{c}\text { WLQ } \\
\text { Productivity }\end{array}$ \\
\hline GT & 30.3 & & \\
DF & 40.8 & 0.08 & $8.8 \%$ \\
DMI & 29.6 & & \\
DP & 30.5 & & \\
\hline
\end{tabular}

$X=$ Média; GT - gerência do tempo; DF - demanda física; DMI - demanda mental-interpessoal, $D P$ - demanda de produção. WLQ Domínio - WLQ Scale Score; WLQ Índice - WLQ Index; WLQ Produtividade - WLQ At-Work Productivity Loss Index.

Analysis of the association of the general index of WLQ and the scores of its domains with variables of health and work conditions are shown in Table 3. 
Table 3 - Association of the Work Limitations Questionnaire Index (WLQ) and its domains with the variables of nursing professionals' working conditions and health at a Municipal Hospital and Emergency Room, Center-West, Brazil, 2019-2020 ( $n=306)$ *

\begin{tabular}{|c|c|c|c|c|c|c|}
\hline Variable & Domains & $\mathbf{n}$ & Mean & Median & $\mathbf{S D}^{+}$ & $p$ value $^{\ddagger}$ \\
\hline Type of contraction & \multirow[t]{3}{*}{ WLQ Index } & & & & & \multirow[t]{3}{*}{0.002} \\
\hline Consolidation of Labor Laws & & 182 & 10.0 & 8.5 & 6.7 & \\
\hline Permanent & & 110 & 7.8 & 5.2 & 6.5 & \\
\hline Consolidation of Labor Laws & \multirow[t]{2}{*}{ Mental-interpersonal demand } & 184 & 34.9 & 29.1 & 28.4 & \multirow[t]{2}{*}{$<0.001$} \\
\hline Permanent & & 111 & 23.2 & 13.9 & 25.2 & \\
\hline Consolidation of Labor Laws & \multirow[t]{2}{*}{ Production demand } & 182 & 35.4 & 35.0 & 30.6 & \multirow[t]{2}{*}{0.003} \\
\hline Permanent & & 111 & 25.2 & 10.0 & 29.8 & \\
\hline Sector of activity & \multirow[t]{3}{*}{ Physical demand } & & & & & \multirow[t]{3}{*}{0.008} \\
\hline Inpatient clinics & & 213 & 38.5 & 33.3 & 31.0 & \\
\hline Intensive Care Unit & & 93 & 46.2 & 45.8 & 26.2 & \\
\hline \multirow{3}{*}{\multicolumn{2}{|c|}{$\begin{array}{l}\text { Practice activity twice a week } \\
\text { Yes } \\
\text { No }\end{array}$}} & & & & & \multirow[t]{3}{*}{0.008} \\
\hline & & 32 & 28.6 & 25.0 & 27.40 & \\
\hline & & 230 & 41.9 & 37.5 & 29.0 & \\
\hline
\end{tabular}

Table 4 - Distribution of musculoskeletal symptoms by body regions of nursing workers in a hospital and municipal emergency room, Center-West, Brazil, 2019-2020 ( $n=306)$

\begin{tabular}{|c|c|c|}
\hline & $\begin{array}{l}\text { In the past } 12 \text { months, } \\
\text { have you had any } \\
\text { problems, such as pain, } \\
\text { tingling/numbness, in? } \\
(\%)\end{array}$ & $\begin{array}{c}\text { In the past } \\
7 \text { days, have } \\
\text { you had any } \\
\text { problems with? } \\
(\%) \\
\end{array}$ \\
\hline - Neck & 20.3 & 9.5 \\
\hline Shoulders & 20.0 & 6.2 \\
\hline - Upper back & 25.2 & 11.1 \\
\hline - Elbows & 3.3 & 1.6 \\
\hline Wrists/hands & 11.4 & 3.6 \\
\hline Lower back & 28.1 & 13.4 \\
\hline Hip/thighs & 14.4 & 5.9 \\
\hline Knees & 17.0 & 6.9 \\
\hline 80 Ankles/feet & 17.3 & 7.8 \\
\hline
\end{tabular}

It was found, when analyzing the general score of SPS6 with the general score of the WLQ domains, a significant association of presenteeism with the physical demand domain $(p<0.0001)$ (mean 48.8, median 45.8 and SD=30,7), representing greater losses among presenteeists in the execution of tasks that require body strength, endurance, movement, coordination and flexibility.

In relation to the work shift, professionals who worked at night, on a 12/36 hour basis, showed greater impairment in the overall SPS6 score $(p=0.011)$ (mean 17.7, median 18 and SD=3.2). This group of professionals also showed a significant association with the finished work dimension in SPS6, when compared with those who work 6 to 8 hours a day $(p=0.011)$ (mean 7.8, median 7 and SD=2.9). There were no significant associations between the variables of the study and the maintained concentration dimension for that instrument. There were also no significant associations with the use of tobacco, alcohol, medications of regular use and OA occurrence in the last year.

The responses referring to QNSO showed that the lower back was the most affected, and the data are shown in Table 4.

Table 5 - Association of musculoskeletal symptoms in the last 12 months and in the last 7 days according to the Nordic Musculoskeletal Questionnaire with the self-declaration of working with any health problem, according to the Stanford Presenteeism Scale (SPS6) in nursing professionals of a hospital and municipal emergency room, Center-West, Brazil, 2019-2020 $(n=306) *(n=134)^{\dagger}$

\begin{tabular}{|c|c|c|c|c|c|c|c|}
\hline $\begin{array}{l}\text { Variables (pain/tingling/ } \\
\text { numbness in the last } 12 \text { months) }\end{array}$ & $\begin{array}{l}\text { SPS6-Yes } \\
\text { n(\%) }\end{array}$ & $\begin{array}{c}\text { SPS6-No } \\
\text { n(\%) }\end{array}$ & $\underset{\text { value }^{p}}{p}$ & $\begin{array}{l}\text { Variables (pain/tingling/ } \\
\text { numbness in the last } 7 \text { days) }\end{array}$ & $\begin{array}{l}\text { SPS6-Yes } \\
\text { n(\%) }\end{array}$ & $\begin{array}{c}\text { SPS6-No } \\
\text { n(\%) }\end{array}$ & $\underset{\text { value }^{\ddagger}}{p}$ \\
\hline Neck & & & 0,001 & Neck & & & 0,007 \\
\hline Yes & $39(12,7)$ & $23(7,5)$ & & Yes & $20(6,5)$ & $9(2,9)$ & \\
\hline No & $95(31,0)$ & $149(48,7)$ & & No & $114(37,3)$ & $163(53,3)$ & \\
\hline Shoulders & & & 0,001 & Shoulders & & & 0,127 \\
\hline Yes & $38(12,5)$ & $23(7,5)$ & & Yes & $12(3,9)$ & $7(2,3)$ & \\
\hline No & $95(31,1)$ & $149(48,9)$ & & No & $121(39,8)$ & $164(53,9)$ & \\
\hline Upper Back & & & $<0,000$ & Upper Back & & & 0,005 \\
\hline Yes & $48(15,7)$ & $29(9,5)$ & & Yes & $23(7,5)$ & $11(3,6)$ & \\
\hline No & $86(28,1)$ & $143(46,7)$ & & No & $111(36,3)$ & $161(52,6)$ & \\
\hline Lower back & & & 0,001 & Lower back & & & 0,026 \\
\hline Yes & $51(16,7)$ & $35(11,4)$ & & Yes & $25(8,2)$ & $16(5,2)$ & \\
\hline No & $83(27,1)$ & $137(44,8)$ & & No & $109(35,6)$ & $161(52,6)$ & \\
\hline Hips/thighs & & & 0,002 & Hips/thighs & & & 0,001 \\
\hline Yes & $29(9,5)$ & $15(4,9)$ & & Yes & $15(4,9)$ & $3(1,0)$ & \\
\hline No & $105(34,3)$ & $157(51,3)$ & & No & $119(38,9)$ & $169(55,2)$ & \\
\hline Knees & & & 0,001 & Knees & & & 0,004 \\
\hline Yes & $31(10,1)$ & $21(6,9)$ & & Yes & $16(5,2)$ & $5(1,6)$ & \\
\hline No & $103(43,8)$ & $151(49,3)$ & & No & $118(38,6)$ & $167(54,6)$ & \\
\hline Ankles/feet & & & 0,004 & & & & -- \\
\hline Yes & $33(10,8)$ & $20(6,5)$ & & & -- & -- & \\
\hline No & $101(33,0)$ & $152(49,7)$ & & & -- & -- & \\
\hline
\end{tabular}


The data presented in Table 5 show the associations of musculoskeletal symptoms presented in the last 12 months and in the last 7 days prior to data collection, respectively, when compared with SPS6. No significant associations were found between QNSO and WLQ.

\section{DISCUSSION}

The sociodemographic findings corroborate research that assessed the social profile and nursing professionals in Brazil, showing a predominantly female audience in the country. The technical professional category stands out as the largest workforce in the area, followed by professional nurses who add up to a total of $1,694,562$ professionals in the country, under the age of $60^{(20-21)}$.

It was observed that most of participants have a contract governed by CLT in the form of an indefinite contract, followed by service providers and/or commissioned positions. Such findings are in line with the profile of nursing in Brazil, characterized by statutory professionals who represent a frequency of less than $50 \%{ }^{(22)}$.

Of the nursing professionals assessed in this research as presenteeists by SPS6, more than $40 \%$ of the population was classified with a low score (between 6 and 18 points), characterized by a reduction in their work performance, and dimension 1 of that instrument showed that the finished work corresponding to the physical aspects was the most impaired. A study carried out in an ICU of a large hospital in Brazil, using the same data collection instrument, found an association between the present professionals, with the performance in the respective sector and greater involvement of female professionals. It is noteworthy that the dimension that represents the finished work was also the most affected ${ }^{(10)}$, corroborating the findings of this study.

Another study, which sought to assess the prevalence of presenteeism in 151 Portuguese nurses, showed that $91.4 \%$ of these professionals went to work in the last month regarding data collection with one or more health problems, which demonstrates the high rate of presenteeism in the studied group. Still on the same study, the author identified, among the main factors that led to presenteeism in nurses, low back pain (57.0\%) as the main symptom, showing greater physical impairment and worse performance at work ${ }^{(5)}$.

An investigation carried out with nursing professionals from three ICUs in Salvador, Brazil, found that the quality of life of these professionals was affected in the physical (63.0\%), psychological (65.44\%), social relationships (62.71\%) and environment (52.73\%). Such factors, when mitigated by labor policies of better working conditions for these professionals, taking into account the high stressors they are subjected to in the face of the criticality of patients they assist, favor a more productive work environment. It has been observed in this investigation that, considering the numerous repercussions to presenteeism, drop in productivity has had a great impact, especially among professionals in critical units, with the physical domain of the quality of life construct being the most affected ${ }^{(23)}$.

In an investigation carried out with 340 Chinese nurses, who assessed factors related to presenteeism through SPS6, it was identified that the phenomenon was related to drop in productivity mediated by health conditions. In addition, management investment in improving the level of general self-efficacy among workers was recommended as a way to mitigate this impact ${ }^{(24)}$.

It was observed, on the general score of WLQ, that there were significant associations as to the type of hiring of these workers, since those with a hired worker were more committed when compared to permanent workers. Regarding the type of hiring, a significant association was observed between this variable and the mental-interpersonal domains and demand for production, characterizing workers with a formal employment relationship, with greater loss of productivity when compared to those whose labor regulations are statutory. It is believed and inferred that this factor may be related to the differentiation of working hours between these professionals as well as to the benefits arising from the respective type of bond established between employee and employer. There was a great variability of workload in the study institution and different ways of hiring professionals.

When assessing the WLQ domains and its repercussions on worker productivity, workers who work in ICU had greater losses when compared to those who work in other sectors of the hospital, with the physical demand domain being the most affected, therefore responsible for the biggest drop in productivity of these professionals.

Still on the WLQ demands, a survey conducted in Japan, with 1,100 nurses, aiming to investigate the relationship between low back pain and productivity in the observed group, concluded that the prevalence of this symptom was $65 \%$, showing a significant association in the domains of time, mental-interpersonal demand and production demand ${ }^{(25)}$. Therefore, it is possible to infer that presenteeism may be mainly related to musculoskeletal symptoms, having as one of its main consequences to drop in productivity, corroborating the results presented in this study.

In the physical demand domain of that scale, there was a significant association when compared to the sector in which participants worked, evidenced by greater impairment of productivity among professionals who worked in ICU, revealing the respective sector as a work environment that can bring greater ergonomic risks to workers.

Also in this same domain, a significant association with the practice of physical activity was also evidenced at least twice a week, since workers who referred to the respective activity routine had a lower drop in productivity.

Literature advises that the practice of physical activity, on a regular basis and at sufficient levels, with a minimum frequency of 150 minutes per week of activities of moderate intensity or equivalent or 75 minutes with vigorous intensity, is able to assist in the prevention of chronic diseases and to improve the physical and mental performance of individuals in their activities of daily living, which can assist in better productivity at work ${ }^{(26-28)}$, as evidenced by the results found in this investigation.

With regard to workload and shift of professional activity, the greatest frequency in this study was that of workers who worked in the modality of duty on a scales regime, which most of them exceed 30 hours a week, similar to the findings of other investigations ${ }^{(22,29)}$. Such results, when compared with data from literature, show that those professionals who worked long hours, as well as at night, have higher risks of illness related to 
the physical aspect. A study carried out with 98 nursing professionals from a psychiatric hospital in northeastern Brazil showed that musculoskeletal pain (upper limbs and back) were the most prevalent symptoms in this group of workers ${ }^{(29)}$.

In a study carried out in the Principality of Asturias in Spain, with 323 hospital health professionals, of which $47.7 \%$ were nursing professionals, there was a $52.9 \%$ rate of presenteeism in the studied sample, concluding that pain was the most frequent symptom (32.2\%). This investigation also highlighted that the type of hiring of nursing workers was represented by more than $70 \%$ as non-statutory, according to the country's labor regulations, with these professionals having the highest rates of presenteeism ${ }^{(7)}$, reinforcing the findings of this research.

Musculoskeletal symptoms have also been shown to be an important problem among nursing workers, whose repercussions are measurable for both the sick professional and the institutions, since the impacts increase the cases of absenteeism among workers and affect the productivity of these professionals due to the disabilities they cause ${ }^{(30-31)}$.

The results indicated pain in the lower back as the major complaint of this symptom among participants, both in the last 12 months and in the last 7 days prior to data collection, which shows that the nursing team has been sick, mainly due to musculoskeletal disorders, as concluded in other national and international investigations s, $^{(29,31-33)}$.

A study emphasizes that, given the great responsibility of nursing in relation to care, the good health status of these professionals is essential to qualify their work, bringing to light the need for managers to be aware that it is an emerging problem in health services and that control measures are necessary for workers to fulfill their professional and social role in the market, bringing them health assurance in their work environment ${ }^{(34)}$.

Still with regard to ergonomic risks and their consequences for workers, international studies have found values above $70 \%$ of musculoskeletal symptoms among nursing workers. In Brazil, this record exceeded $80 \%$, with pain being described as the symptom most often cited by this category ${ }^{(33,35-36)}$. The repercussions of these injuries are numerous and the consequences generated can lead to the removal of professionals from their activities as well as causing a decrease in their ability to work or the inability to do so ${ }^{(32,35)}$.

In addition to presenteeism, a major consequence also presented by this grievance is the future absenteeism, as reported by literature ${ }^{(3,37)}$. A prospective study carried out in Sweden, with 43,862 nursing professionals, identified that retirement/disability leave was related to those who declared to have been presenteeists for at least 4 times in the last 12 months preceding data collection ${ }^{(38)}$, which led to a substantial increase in social security spending, public spending and personal repercussions on the lives of these affected workers. Such results from literature corroborate the findings of this investigation, since the high rates of presenteeism were related to musculoskeletal symptoms both in the last 12 months and in the last 7 days prior to data collection.

It is emphasized that the results of this study are in line with the Brazilian National Agency for Health Research Priorities (Agência Nacional de Prioridades de Pesquisa em Saúde) recommendations ${ }^{(14)}$, that guide the realization of researches that assess the economic impact for SUS referring to work-related injuries, as well as their direct and indirect costs for the service. It reinforces the search for data that establish a relationship between productivity and professional health bonds in SUS, corroborating the main results of this investigation, since the productive impact caused by presenteeism among the subjects studied here was notorious.

With regard to nursing, national literature reinforces the Sustainable Health Agenda for the Americas: 2018-2030 (ASSA 2030) recommendations, prepared by the Pan American Health Organization and adopted by the United Nations, which seeks to strengthen changes worldwide based on sustainable development for investments in research. This agenda has 17 goals and 169 objectives to be achieved by governments, companies, universities and citizens; among them, we highlight the encouragement to strengthen management and the development of human resources for health, with competencies that support a comprehensive approach for subjects ${ }^{(39)}$.

To this end, the aforementioned prerogatives encourage improvements in employment conditions, adequate remuneration and the strengthening of governance and leadership by health professionals. Therefore, the availability of scientific evidence that portrays the health situation of this category, especially in the context of nursing workers, as they are the largest quantity of workforce for this purpose, it can offer conditions to propose new public policies and, with that, improvements in the labor structures offered to these professionals ${ }^{(39)}$.

In this way, the present study made it possible to identify that presenteeism may be related, mainly to musculoskeletal symptoms among nursing workers, to the type of bond established between employee and employer and to the sector of activity and their health conditions, such as the practice of physical activity. Furthermore, there is an alert for drop in productivity and the repercussions on professionals' lives and on institutions, health problems that are often not considered.

\section{Study limitations}

Among the study limitations is the fact that it was carried out in only one institution and with only one professional category in the health field stands out, which can negatively interfere with the external validity of the findings. Therefore, it is suggested that further investigations be carried out in health institutions in different regions of the country and with other professionals in this area.

\section{Contributions to nursing, health, and public policies}

Such results are of paramount importance, as it deals with nursing workers' health in a specific way, bringing some important problems related to work and the impact that this brings to organizations, since productivity was shown to be impaired among the population studied. Understanding these relationships present in the workplace, among them in nursing, is the principle for solid discussions about the importance of quality of life at work and its impacts on workers' health, which can also reflect on professional satisfaction and, consequently, assistance to customers. 


\section{CONCLUSIONS}

The results of the study confirmed the high rate of presenteeism and drop in productivity among nursing workers. The presence of musculoskeletal symptoms, the type of employment relationship, shift and place of work and health conditions were the main factors that may be related to injuries. For that, it is necessary to emphasize that the precarious working conditions, the relationships between managers and their collaborators, the degree of accessibility that one has for leadership for dialogue, the sizing of appropriate personnel, among others, are relevant aspects to be considered by the management of health services, in order to mitigate the occurrences of professional exhaustion that lead to the expressive number of absenteeism due to health conditions and that can cause serious damage to the physical, emotional and work life of these professionals, a group that represents the vast majority of those who care for citizens' health in Brazil. Remembering that it is not only institutional expenses that are affected, but also quality of care for patients at different levels of care.

Thus, this research contributes to the advancement of nursing knowledge and aspects that permeate illness related to nursing work, allowing the strengthening of discussions on the theme and the creation of effective labor policies that contribute to professionals' health, in addition to favoring the possibility of reproducing the study with other categories of workers and in other national and international work environments.

\section{REFERENCES}

1. Aronsson G, Gustafsson K, Dallner M. Sick but yet at work: an empirical study of sickness presenteeism. J Epidemiol Community Health [Internet]. 2000 [cited 2018 Dec 8];54(7):502-9. Available from: https://jech.bmj.com/content/jech/54/7/502.full.pdf

2. Bockerman P, Laukkanen E. Predictors of sickness absence and presenteeism: does the pattern differ by a respondent's health? J Occup Environ Med[Internet]. 2010 [cited 2020 Mar 5];52(3):332-5. Available from: 10.1097/JOM.0b013e3181d2422f

3. Shimabuku $\mathrm{RH}$, Mendonça $\mathrm{H}$, Fidelis A. [Presenteeism: contributions of the control-demand model for a phenomenon understanding]. Cad Psicol Soc Trab [Internet]. 2017 [cited 2020 Feb 22];20(1):65-78. Available from: http://www.revistas.usp.br/cpst/article/view/149103/146207. Portuguese.

4. Hansen CD, Andersen JH. Going ill to work: what personal circumstances, attitudes and work-related factors are associated with sickness presenteeism? Soc Sci Med [Internet]. 2008 [cited 2018 Dec 5];67(6):956-64. Available from: https://www.sciencedirect.com/science/article/ abs/pii/S0277953608002748

5. Barbosa DSF. Presente mas ausente: o fenómeno do presentismo em enfermeiros Portugueses [Dissertação][Internet]. Porto: Escola Superior de Enfermagem do Porto; 2016 [cited 2020 Feb 10]. Available from: https://comum.rcaap.pt/bitstream/10400.26/17532/1/ Disserta\%C3\%A7\%C3\%A30\%20de\%20Mestrado_Daniela\%20Barbosa.pdf

6. Carvalho DP, Rocha LP, Tomaschewski-Barlem JG, Barlem ELD, Cecagno D, Dalmolin GL. Productivity versus workloads in the nursing working environment. Rev Esc Enferm USP [Internet]. 2017 [cited 2020 Jan 12]:51:e03301. Available from: https://www.scielo.br/pdf/reeusp/ v51/1980-220X-reeusp-S1980-220X2017028903301.pdf

7. Sanchez-Zaballos M, Baldonedo-Mosteiro M, Monteiro-Díaz MP. [Presenteeism among emergency health care staff]. Emergencias [Internet]. 2018 [cited 2020 Feb 22];30(1):35-40. Available from: http://emergencias.portalsemes.org/descargar/presentismo-en-profesionalessanitarios-de-los-servicios-de-urgencias-y-emergencias/. Spanish.

8. Umann, J, Guido LA, Grazziano ES. Presenteeism in hospital nurses. Rev Latino-Am Enfermagem[Internet]. 2012 [cited 2020 Jan 10]:20(1):159-66. Available from: https://www.scielo.br/pdf/rlae/v20n1/21.pdf

9. Veale PM, Vayalumkal JV, McLaughlin K. Sickness presenteeism in clinical clerks: negatively reinforced behavior or an issue of patient safety? Am J Infect Control[Internet]. 2016 [cited 2020 Mar 6];44(8):892-7. Available from: https://www.ajicjournal.org/article/S0196-6553(16)00149-8/fulltext

10. Silva AF, Robazzi MLCC, Dalri RCMB, Silveira-Monteiro CA, Mendes AMOC. Presenteeism in multiprofessional team workers in the Adult Intensive Care Unit. Rev Bras Enferm [Internet]. 2019 [cited 2020 Feb 10];72(Suppl 1):96-104. Available fom: https://www.scielo.br/pdf/reben/v72s1/00347167-reben-72-s1-0096.pdf

11. Oliveira ALCB, Costa GR, Fernandes MA, Gouveia MTO, Rocha SS. [Presenteeism: factors of risk and repercussions on the health of nursing workers]. Av Enferm [Internet]. 2018 [cited 2020 Feb 25];36(1):79-87. Available from: http://www.scielo.org.co/pdf/aven/v36n1/0121-4500aven-36-01-00079.pdf. Portuguese.

12. Paschoalin HC, Griep RH, Lisboa MTL. [The scientific production on presence in nursing and its impacts on caring]. Rev APS [Internet]. 2012 [cited 2020 Oct 20];15(3):306-11.Available from: https://periodicos.ufjf.br/index.php/aps/article/view/15054. Portuguese.

13. Ministério da Saúde (BR). Secretaria de Ciência, Tecnologia e Insumos Estratégicos. Departamento de Ciência e Tecnologia. Agenda nacional de prioridades de pesquisa em saúde [Internet]. 2. ed. 4. reimpr. Brasília: Ministério da Saúde; 2015 [cited 2019 Dec 13]. Available from: http://brasil.evipnet.org/wp-content/uploads/2017/07/ANPPS.pdf Portuguese.

14. Ministério da Saúde (BR). Secretaria de Ciência, Tecnologia e Insumos Estratégicos. Departamento de Ciência e Tecnologia. Agenda de Prioridades de Pesquisa do Ministério da Saúde [Internet]. Brasília: Ministério da Saúde; 2018 [cited 2020 Feb 26]. Available from: http:// bvsms.saude.gov.br/bvs/publicacoes/agenda_prioridades_pesquisa_ms.pdf

15. Koopman C, Pelletier KR, Murray JF, Sharda CE, Berger ML, Turpin RS, et al. Standford presenteeism scale: health status and employee productivity. J Occup Environ Med [Internet]. 2002 [cited 2020 Feb 8];44(1):14-20. Available from: https://journals.Iww.com/joem/ Abstract/2002/01000/Stanford_Presenteeism_Scale_Health_Status_and.4.aspx 
16. Soárez PC, Kowalski CCG, Ferraz MB, Ciconelli RM. [Translation into Brazilian Portuguese and validation of the Work Limitations Questionnaire]. Rev Panam Salud Pública [Internet]. 2007 [cited 2019 Jul 9];22(1):21-8. Available from: https://scielosp.org/pdf/rpsp/2007. v22n1/21-28/pt Portuguese.

17. Lerner D, Amick BC, Rogers WH, Malspeis S, Bungay K, Cynn D. The work limitations questionnaire. Med Care [Internet]. 2001[cited 2019 Aug 10];39(1):72-85. Available from: https://journals.Iww.com/lww-medicalcare/Fulltext/2001/01000/ The_Work_Limitations_Questionnaire.9.aspx

18. Kuorinka I, Jonsson B, Kilbom A, Vinterberg H, Biering-Sørensen F, Andersson G, et al. Standardised Nordic questionnaires for the analysis of musculoskeletal symptoms. Appl Ergon [Internet]. 1987 [cited 2018 Dec 15];18(3):233-7. Available from: https://www.sciencedirect.com/ science/article/abs/pii/000368708790010X?via\%3Dihub

19. Pinheiro FA, Troccoli BT, Carvalho CV. Validação do Questionário Nórdico de Sintomas Osteomusculares como medida de morbidade. Rev Saúde Pública[Internet]. 2002 [cited 2020 Feb 16];36(3);307-12. Available from: https://www.scielo.br/pdf/rsp/v36n3/10492.pdf

20. Silva MCN, Machado MH. Health and work system: challenges for the nursing in Brazil. Cienc Saude Colet [Internet]. 2020 [cited 2020 Mar 10];25(1):7-13. Available from: https://www.scielo.br/pdf/csc/v25n1/en_1413-8123-csc-25-01-0007.pdf

21. Assunção AA, Pimenta AM. Job satisfaction of nursing staff in the public health network in a Brazilian capital city. Cienc Saude Colet. [Internet]. 2020 [cited 2020 Mar 10];25(1):169-80. Available from: https://www.scielo.br/pdf/csc/v25n1/en_1413-8123-csc-25-01-0169.pdf

22. Machado MH, Koster I, Aguiar Filho W, Wermelinger MCMW, Freire NP, Pereira EJ. Labor market and regulatory processes - nursing in Brazil. Cienc Saude Colet [Internet]. 2020 [cited 2020 Mar 10];25(1):101-12. Available from: https://www.scielo.br/pdf/csc/v25n1/en_1413-8123csc-25-01-0101.pdf

23. Li Y, Zhang J, Wang S, Guo S. The effect of presenteeism on productivity loss in nurses: the mediation of health and the moderation of general self-efficacy. Front Psychol [Internet]. 2019 [cited 2020 Feb 13];10:1745. Available from: https://www.frontiersin.org/ articles/10.3389/fpsyg.2019.01745/full

24. Yokota J, Fukutani N, Nin K, Yamanaka H, Yasuda M, Tashiro Y, et al. Association of low back pain with presenteeism in hospital nursing staff. J occup health. [Internet]. 2019 [cited 2020 Feb 22];61(3):219-26. Available from: https://onlinelibrary.wiley.com/doi/ pdf/10.1002/1348-9585.12030

25. World Health Organization-WHO. Global health risks: mortality and burden of disease attributable to selected major risks [Internet]. Geneva: WHO; 2009 [cited 2020 Mar 5]. Available from: https://www.who.int/healthinfo/global_burden_disease/GlobalHealthRisks_report_full.pdf

26. World Health Organization-WHO. Global recommendations on physical activity for health [Internet]. Geneva: WHO; 2010 [cited 2020 Mar 5]. Available from: https://apps.who.int/iris/bitstream/handle/10665/44399/9789241599979_eng.pdf?sequence=1

27. Ministério da Saúde (BR). Secretaria de Vigilância em Saúde. Departamento de Vigilância de Doenças e Agravos não transmissíveis e Promoção da Saúde. Vigitel Brasil 2014 : vigilância de fatores de risco e proteção para doenças crônicas por inquérito telefônico [Internet]. Brasília: Ministério da Saúde; 2015 [cited 2020 Feb 18]. Available from: http://bvsms.saude.gov.br/bvs/publicacoes/vigitel_brasil_2014.pdf

28. Sousa KHJF, Zeitoune RCG, Portela LF, Tracera GMP, Moraes KG, Figueiró RFS. Factors related to the risk of illness of nursing staff at work in a psychiatric institution. Rev Latino-Am Enfermagem. [Internet]. 2020 [cited 2020 Mar 6];28:e3235. Available from: https://www.scielo.br/pdf/ rlae/v28/0104-1169-rlae-28-e3235.pdf

29. Galindo IS, Ferreira SCM, Lazzari DD, Kempfer SS, Testonii AK. Motivos do absenteísmo em uma equipe de enfermagem ambulatorial. Rev Enferm UFPE [Internet]. 2017 [cited 2020 Jan 17]:11(Suppl. 8):3198-205. Available from: https://periodicos.ufpe.br/revistas/ revistaenfermagem/article/view/110184/22064

30. Silva RF, Silva SF, Almeida NM, Barbosa TC, Quaresma FRP, Maciel ES. Presence of musculoskeletal disorders among nurses working in emergency care units. Rev Enferm Atenção Saúde [Internet]. 2017 [cited 2020 Feb 6];6(2):2-10. Available from: http://seer.uftm.edu.br/ revistaeletronica/index.php/enfer/article/view/2081/pdf_1

31. Petersen RS, Marziale MHP. Análise da capacidade no trabalho e estresse entre profissionais de enfermagem com distúrbios osteomusculares. Rev Gaúcha Enferm [Internet]. 2017 [cited 2020 Mar16];38(3):e67184. Available from: https://www.scielo.br/pdf/rgenf/ v38n3/en_0102-6933-rgenf-38-3-e67184.pdf

32. Santos HEC, Marziale MHP, Felli VE. A. Presenteeism and musculoskeletal symptoms among nursing Professionals. Rev Latino-Am Enfermagem [Internet]. 2018 [cited 2020 Feb 22];26:e3006. Available from: https://www.scielo.br/pdf/rlae/v26/0104-1169-rlae-26-e3006.pdf

33. Baldonedo-Mosteiro M, Sanchez-Zaballos M, Rodriguez-Diaz FJ, Herrero J, Mosteiro-Diaz MP. Adaptation and validation of the Stanford Presenteeism Scale-6 in healthcare professionals. Int Nurs Rev[Internet]. 2020 [cited 2020 Mar 10];67(1):109-17. Available from: https:// onlinelibrary.wiley.com/doi/pdf/10.1111/inr.12544

34. Tinubu BM, Mbada CE, Oyeyemi AL, Fabunmi AA. Work-related musculoskeletal disorders among nurses in lbadan, South-west Nigeria: a cross-sectional survey. BMC Musculoskelet Disord [Internet] 2010 [cited 2018 Nov 10];11(12). Available from: https:// bmcmusculoskeletdisord.biomedcentral.com/articles/10.1186/1471-2474-11-12

35. Attar SM. Frequency and risk factors of musculoskeletal pain in nurses at a tertiary centre in Jeddah, Saudi Arabia: a cross sectional study. BMC Res Notes [Internet]. 2014 [cited 2020 Feb 15];7(61). Available from: https://bmcresnotes.biomedcentral.com/ articles/10.1186/1756-0500-7-61

36. Silva Jr FF, Merino EAD. Proposal for management of absenteeism among hospital nurses: a systematic review. Acta Paul Enferm [Internet]. 2017 [cited 2020 Feb 10];30(5):546-53. Available from: https://www.scielo.br/pdf/ape/v30n5/en_0103-2100-ape-30-05-0546.pdf 
37. Gustafsson K, Bergström G, Marklund S, Aboagye E, Leineweber C. Presenteeism as a predictor of disability pension: a prospective study among nursing professionals and care assistants in Sweden. J Occup Health[Internet]. 2019 [cited 2020 Mar 7]:61(6):453-63. Available from: https://onlinelibrary.wiley.com/doi/pdf/10.1002/1348-9585.12070

38. Marziale MHP. Nursing research priorities in light of the sustainable development goals: the 2030 agenda. Aquichan[Internet]. 2019 [cited 2020 Jan 17]:19(2):e1921. Available from: http://www.scielo.org.co/pdf/aqui/v19n2/1657-5997-aqui-19-02-e1921.pdf

39. Pan American Health Organization. Sustainable health agenda for the Americas 2018-2030: a call to action for health and wellbeing in the Region [Internet]. Washington, DC: PAHO/WHO; 2017 [cited 2019 Jun 3]. Available from: https://iris.paho.org/bitstream/ handle/10665.2/49170/CSP296-eng.pdf?sequence=1 1 \&isAllowed $=y$ 